\title{
THE POTENTIAL OF WAQF FOR MAINTENANCE AND MANAGEMENT OF STRATIFIED PROPERTIES IN MALAYSIA *
}

\author{
Nor Asiah Mohamad ${ }^{* *}$ \\ Azlinor Sufian ${ }^{*}$ \\ Sharifah Zubaidah Syed Abdul Kader ${ }^{* * * *}$
}

\begin{abstract}
This article explores the possibility of implementing the concept of waqf within the financial management of a strata scheme for the purpose of covering the costs to maintain and manage common properties. High prices of land and the lack of strategic locations for housing has influenced developers to opt for stratified development. The challenge, most of the time, pertains to the maintenance of common areas, which requires substantial funds and professionalism, as well as skills in developing social and human relationships, despite the continual increase in the costs of management. Using doctrinal analysis of primary and secondary data, as well as comparative analysis with strata regulations in Australia, the study concludes that cash waqf can play a role as a potential vehicle to raise funds to maintain and manage common properties in strata schemes. The
\end{abstract}

This article is an improved version based on earlier paper presented in International Conference on Waqaf, Trust and Endowment 2015, Russian Academy of National Economics and Political Administration, Moscow, 28th September 2015 to 1st October 2015. The research was supported by the Ministry of Higher Education (MOHE) under the Research Initiative Grant (RIGS) No. RIG-16-267-0431. The authors record their appreciation to the IIUM Research Management Centre for facilitating the research project. The contents of this article are entirely the responsibility of the authors and do not reflect the official views of MOHE or IIUM.

** Associate Professor, Civil Law Department, Ahmad Ibrahim Kulliyyah of Laws, International Islamic University Malaysia, nasiahm@iium.edu.my Assistant Professor, Legal Practice Department, Ahmad Ibrahim Kulliyyah of Laws, International Islamic University Malaysia.

**** Director, International Centre for Waqf Research, International Islamic University Malaysia. 
concept of waqf, where a certain category of properties is released from the ownership of man permanently while its benefits are dedicated to be used for the betterment of the public (ummah), is now regarded as a catalyst for the third sector economy. While religious reward may motivate Muslim owners or tenants to contribute to the waqf fund, other benefits offered such as financial security, sustainability, accountability and transparency would invite contribution and build trust from both, Muslims and non-Muslims. With adequate awareness, initiatives, and effective marketing of waqf products, the waqf concept would be able to provide a sustainable source of funds to cater to short term and long term maintenance plans for strata schemes.

Keywords: waqf, stratified properties, common properties, maintenance charges, sinking fund

\title{
POTENSI WAKAF UNTUK PENYELENGGARAAN DAN PENGURUSAN HARTANAH STRATA DI MALAYSIA
}

\begin{abstract}
ABSTRAK
Makalah ini meneroka kemungkinan mengaplikasi konsep wakaf dalam pengurusan kewangan skim strata untuk memenuhi kos penyelenggaraan dan pengurusan harta bersama. Nilai tanah yang semakin tinggi serta kurangnya hartanah di lokasi yang strategik menyumbang kepada kecenderungan pemaju-pemaju perumahan untuk membina rumah bertingkat. Cabaran utama pengurusan harta strata ialah untuk memastikan sumber kewangan yang cukup dan terjamin serta memastikan bahawa pengurus adalah orang yang berpengalaman bukan sahaja dalam pengurusan harta tetapi juga pengurusan asset kewangan supaya jaminan sumber kewangan terjamin. Menggunakan metod analisa data utama dan sekunder, beserta analisa perbandingan dengan undang-undang strata di Australia, dapatan kajian menunjukkan bahawa skim wakaf merupakan salah satu pendekatan pengurusan yang boleh digunapakai bagi skim strata. Wakaf tunai boleh diaplikasikan sebagai metod untuk dijadikan modal aset wakaf strata. Ini berdasarkan dapatan bahawa ciri wakaf yang kekal, tidak boleh dilupuskan secara sewenangnya serta tujuan kemaslahatan umum merupakan ciri yang selari dalam pengurusan wakaf dan wakaf dilihat sebagai pemangkin sektor ketiga ekonomi. Malah, sistem kutipan caj
\end{abstract}


penyelenggaraan yang diamalkan dapat digunapakai juga untuk sumbangan wakaf berkala dan lebih telus, terjamin, dipercayai dan bias menarik penderma Islam dan bukan Islam. Dengan peningkatan usaha memberi kesedaran serta pemasaran yang sesuai, produk wakaf amat bersesuaian untuk diperkenalkan dalam pengurusan hak milik strata.

Kata kunci: Wakaf, hartanah strata, harta bersama, caj penyelenggaraan, kumpulan wang penjelas

\section{INTRODUCTION}

This article explores the possibility of implementing waqf within the financial management of a strata scheme for the purpose of covering the costs to maintain and manage the common properties. Such proposal becomes more important today when the Malaysian government is pushing for the development of waqf lands to solve housing woes. Given the high prices of land and the lack of strategic locations for housing, developers have opted for stratified development. Maintenance of stratified properties globally requires common contribution from all owners, financially, ${ }^{1}$ morally ${ }^{2}$ and socially. ${ }^{3}$ The properties can be divided into two categories, viz. self-owned property and the common property. ${ }^{4}$ While self-owned properties are said to be solely under the duty of the owner, practically, these too require cooperation from other owners, as what they own is basically a unit of property that is commonly structured and supported by the properties of other owners. The law is designed to qualify that a parcel owner's right to enjoy his land is always subject to his duty to take care of the properties of others. The most challenging aspect in stratified living is the duty of the managers to

\footnotetext{
Monetary contributions to the maintenance fund and sinking fund.

Obligation not to cause nuisance and to abide by the by laws of the stratified building to maintain harmony in the strata scheme.

3 As a co-owner of common property with other parcel owners. Also to attend and vote during meetings.

4 It refers to so much of the lot as is not comprised in any parcel, as shown in the strata plan and is used and capable of being used or enjoyed by two or more of the parcel owners.
} 
secure sustainable income to finance the maintenance and management of the common property. ${ }^{5}$

This article introduces the legal regime relating to stratified properties in Malaysia, by identifying the relevant parties in a strata scheme as well as examining the management and finances in a strata scheme. It identifies the fact that the management body in a strata scheme already has the power to collect the monthly maintenance charges and contributions to the sinking fund for the purpose of maintenance of the stratified properties, including the common properties. Thus, introducing a cash waqf scheme in addition to these as a strategy for sustainable generation of income to maintain the common property is already in line with the spirit of strata titles law in Malaysia. The article then goes on to discuss two ways in which waqf can be incorporated into the financial management of a strata scheme and proposes two models, one based on cash waqf and the other based on musyarakah sukuk.

\section{NATURE AND BACKGROUND OF STRATA MANAGEMENT LAW}

In Malaysia, there are several laws available to ensure that the unique style of strata living is self regulated and jointly governed by all owners. ${ }^{6}$ There is no doubt that the efficiency of the laws will contribute to the value of the properties. Legally, stratified properties are part of the concept of land ${ }^{7}$ where all matters pertaining to land falls under the jurisdiction of the Ministry of Natural Resources and Environment. The administration of stratified properties is divided into two; strata titles and strata management. Strata management falls under the purview of the Ministry of Urban Well-Being, Housing and Local Government. Having two different ministries may invite problems such as jurisdictional

5 Generally, this refers to the areas and facilities that are used by all strata owners as tenants in common within a strata scheme. Under Section 2 of the Strata Management Act 2013, common property refers to so much of the development area which is not comprised in any parcel or proposed parcel and is used or capable to be used or enjoyed by two or more of the occupiers of the parcel.

6 The Strata Titles Act 1985 (Act 318), the Strata Management Act 2013 (Act 757), the Housing Development (Control and Licensing) Act 1966.

7 Section 5 of the National Land Code 1965. 
overlap, lack of enforcement and confusion among the strata stakeholders on what is the most appropriate mechanism to resolve strata problems.

The first law on strata titles was introduced in 1985, known as the Strata Titles Act 1985. Before 1985, all subdivided properties were governed by provisions in the National Land Code 1965 and as evidenced, cumulative problems arose due to the many unclear positions on matters relating to strata properties. ${ }^{8}$ Among the problems were, lack of provisions dealing with the management of the properties and no proper guideline for strata managers to deal with their properties. Having realised the inadequacy of the law, Parliament introduced the Strata Titles Act 1985 ('STA') in order to specifically deal with matters relating to the issuance of strata titles as well as their management. Nevertheless, the demand for stratified properties increased and the law was inadequate, with loopholes especially on matters pertaining to the management and maintenance of the properties. The government strived to enact a new comprehensive law to address the related issues. As a result, the Malaysian government introduced a new law specifically to deal with the management and maintenance of stratified properties via the Building and Common Property (Maintenance and Management Act) 2007 (Act 663) (The BCPMMA).

In due time, the BCPMMA was also found to be incomprehensive. The laws still could not compel errant parcel owners to pay the maintenance charges, especially recalcitrant and habitual defaulters. ${ }^{9}$ The law categorised failure to pay the maintenance charges as a criminal offence. Unfortunately, the defaulters did not seem to be affected due to lack of enforcement by the authorities. ${ }^{10}$ Nevertheless, the management of stratified properties in Malaysia continued to experience some legal hiccups. The bottom line in strata management is effective management of the Maintenance Fund, in order to ensure that the building is safe and clean, and that the living environment is well taken care of, so as to contribute to competitive sales returns. This then led to the introduction

8 Micheal J Willis, Management Corporation in Malaysia, (Sweet and Maxwell: Asia, 2013), x.

9 Roger Tan, "Resolving Tenancy Disputes", The Star, 12th June 2011, accessed $\quad 4^{\text {th }} \quad$ August, 2015 , http://www.malaysianbar.org.my/members_opinions_and_comments/resolv ing_tenancy_disputes.html.

Ibid. 
of a more comprehensive law on stratified properties management known as the Strata Management Act 2013 (Act 318). ${ }^{11}$ This statute stands as the law governing matters pertaining to the administration and management of stratified properties after the titles are issued by the respective land office. ${ }^{12}$ Hence, apart from the Strata Titles Act 1985 which deals with the issuance of strata titles, the management of stratified properties is governed by the Strata Management Act 2013 ('SMA').

\section{STRATA STAKEHOLDERS}

Strata schemes management involves many stakeholders, namely, strata owners, developers, the management corporation, joint management body, managing agents, the Commissioner of Buildings, the State Authority and other related parties such as the Ministries that are directly involved in the management, viz. the Natural Resources and Environment Ministry as well as the Urban Well-Being, Housing and Local Government Ministry. As such, management and maintenance of a strata scheme is unique as it demands common contribution from all strata owners in all aspects. The anchor to this is the management team lead by the Management Corporation ('MC'). It is a body corporate which comes into existence upon the registration of any certified strata plan. ${ }^{13}$ It has perpetual succession and a common seal and can sue and be sued in its own name. ${ }^{14}$ Similarly, a strata owner or strata owners may take action against their MC for any misdemeanour.

Among the important duties of the MC is to determine and impose the maintenance charges and contribution to the sinking fund. ${ }^{15}$ Apart from having a provision to authorise expenditure for the carrying out of their tasks on maintenance and management of the stratified building, land as well as the common property, the $\mathrm{MC}$ also has wide powers to do all things reasonably necessary to perform their duties. ${ }^{16}$ This provision

11 Which repealed the Building and Common Property (Maintenance and Management Act) 2007.

12 This law came into force on $1^{\text {st }}$ June 2015.

13 Section 2 SMA 2013.

14 Section 17(3) of the STA 1985; Section 59(1)(h) of the SMA 2013.

15 Section 59(1)(b)(c) of the SMA 2013.

16 Section 59(2)(c) and (j) of the SMA 2013. 
can be a basis for the management to employ waqf modes as part of their strategies to raise funds for the management of strata properties and facilities. Such proposal requires endorsement by the members of the MC during the AGM. In this respect, the employment of cash waqf as an instrument to raise funds in stratified properties development as well as management is viable and practical. In practice, the owners of strata units are expected to contribute to their monthly maintenance charges. In other words, stratified property management has a ready-made financial system which facilitates a continuous and sustainable contribution which is in line with the current practice of cash waqf. From a human capital perspective, the existing manpower may only require awareness and specialised training on waqf. In this regard, section 43(2)(f) of the SMA gives wide powers to the MC to do all things necessary to perform their duties.

\section{MANAGEMENT OF A STRATA SCHEME}

The concept of management varies according to the type of properties. There are various types of stratified properties such as commercial properties and residential properties which can be further classified as low cost strata, medium cost or high end strata properties. Some stratified properties may involve a very large-scale project while others are small projects as only a few units of multi-storey buildings and landed properties are constructed. Different types of properties contribute to the volume of budget incurred to maintain the properties. Some stratified properties may have landed properties which are guarded or gated as the current law allows for subdivision of landed properties. ${ }^{17}$

The opportunity to maintain common properties through waqf is perceived to be less problematic in a small-scale strata scheme which sometimes belong to family members. The sense of belonging ${ }^{18}$ will contribute to monetary pledges as well as other services. While the common general principles for strata management would tell us that lesser number of strata owners in a strata scheme requires more contribution for maintenance fees, the scenario may be otherwise for a

17 S. 2 of the STA 1985.

18 In family waqf, this spirit is developed as a way to protect the future generation and security of the family properties. 
strata scheme with waqf management. The pledge for waqf may help the strata owners to rely on profits coming from the waqf benefits, which to a certain extent, and with proper management of the fund would be able to make a strata scheme more independent, thus reducing contributions from each owner.

Stratified properties are generally managed by various stakeholders. If the properties are yet to be subdivided and no individual strata titles are issued to the purchaser of the unit or parcel, the management of the properties are taken care of by the developer. ${ }^{19}$ During the developer management period, the law clearly provides that a developer has a duty to open an account called a maintenance account and to determine the amount of charges to be levied upon the purchasers of the scheme. As a mechanism to ensure proper compliance of the law, a developer is required to provide audited financial statements to all purchasers. The power of the developer during the developers' management period includes to collect the maintenance charges and manage the collection of monthly charges, to collect and manage the collection of the sinking fund, to effect insurance, and to incur costs to do repairs or other works to the common property as provided by the law. ${ }^{20}$

The law only gives the power to the developer to manage the properties for not more than a year and the developer is required to hand over the responsibility to the strata owners under an entity called a Joint Management Body (JMB), who is appointed through an annual general meeting (AGM). During the management of the JMB, the committee shall continue to determine and impose charges to be deposited to the maintenance account as well as to determine the portion of contribution to the sinking fund. After the strata titles are issued, the Management Corporation (MC) which consists of all the strata owners shall be established and subject to subsections 63(4) of the SMA 2013, the MC shall elect a management committee that will perform the MC's duties.

The current strata law provides for a self-regulated regime where the owners are given the right to manage their schemes. The owners, either manage their own strata schemes, or in many cases, appoint strata managers to manage the scheme on their behalf. Hence, eventhough the laws have been put in place, some of the problems remain, especially

19 I.M. Shukri, A Land Administrator's Guide to Strata Titles in Peninsular Malaysia, (Koop PTG: Putrajaya, 2010) 17.

20

S.10 of the SMA 2013. 
matters pertaining to management of fund and maintenance of common properties. Among the main challenges faced by the strata managers is to collect the monthly maintenance charges and contributions to the sinking fund. Maintenance charges are very important for the day to day maintenance of common properties and is to be used for various purposes including:

i) Maintaining the common property in good condition on a day to day basis;

ii) Paying for the expenses incurred in providing cleaning services for the common property, security services and amenities for the occupiers of the buildings;

iii) Paying any premiums for the insurance as provided under the SMA;

iv) Payment with respect to any local authority laws;

v) Minor painting work on premises of common properties;

vi) Paying for carrying inspection of electrical wiring of the common properties, replacing and repairing the faulty system;

vii) Paying for maintenance and repair of water tanks;

viii) Paying rent and rates;

ix) Paying for auditing account works;

x) Paying all charges reasonably incurred for the administration of the accounts required to be maintained by the developer, JMB or the MC under the Act;

xi) Paying remuneration or fees for managing agent who manages the common property on behalf of the developer, JMB or the MC;

xii) paying any expenses, costs or expenditure in relation to the procurement of services, including the engagement of consultants, legal fees or costs and other fees and costs, which are properly incurred by the developer, JMB or the MC in performing their functions and powers according to the laws.

The sinking fund is to be utilised for the special specified purposes, ${ }^{21}$ namely the painting or repainting of any part of the common property; the 
acquisition of any moveable property for the use in relation to the common property; or the renewal or replacement of any fixture or fitting comprised in any common property.

The above shows that the lists of expenditure are clearly guided by the law and as such, the use of waqf instruments, either cash-based or immoveable assets-based, are easily channelled for charitable purposes and will be monitored according to the list. It is also fair to say that strata management is a self-regulated regime where the owners are given the option and has better opportunity in determining the ways in which the stratified building should be managed. Hence, similar to waqf, the donors are given the authority to determine the purpose of the waqf. Given the existence of this statutory list of purposes, the donor would have a better choice in determining the purpose of his waqf accordingly or may opt for waqf am (general) and leave the matter to the discretion of strata managers.

The limited period of management by the developer as well as the Joint Management Body may not be a hindrance to the creation of waqf due to the perpetual nature of waqf and it belonging to Allah (swt). Similar to the nature of common properties, waqf assets remain with the strata scheme. The new management needs to be alerted and made to understand the very special nature of waqf and their sacred objectives. Moreover, the opinions of certain Muslim jurists allowing the temporary waqf provides another golden opportunity for strata managers to use a waqf instrument in stratified properties management. For example, any owner of the strata units may opt to create a temporary waqf $f^{22}$ of his unit so that the benefit may be used for a specific or general purposes of the public or the scheme. Any other interested party may also wish, subject to a certain specified period, to dedicate his property within or outside the strata scheme, the benefit of which may be used for the management or maintenance of specific common properties, for example, for the maintenance of the Muslim prayer room of the scheme or for other general purposes.

22 Temporary waqf is allowed by the Maliki school, and is known as waqf muaqqat (temporal waqf) (Ibn 'Arafah, d 803A.H; Qarafi (d.684 A.H, 6:313). Imam Abu Yousuf also shared a similar view (Sarakhsi, d.490 A.H., 12:41) cited in Iman A.H.M and Sabit M, M.T (2104) Waqf Property, Concept, Management, Development and Financing, UTM, 4647. 


\section{SOURCES OF INCOME IN A STRATA SCHEME}

Management of stratified properties demands continuous funds and capital to manage the common properties, to pay the quit rent, insurance as well as other financial liabilities. Although the scheme itself has its consistent and sustainable income, there are many problems where the owner fails to exercise their duties regularly. As such, strata managers must strategically plan for income generation to provide a sustainable income for their strata schemes. In this respect, waqf may provide an alternative source of sustainable income for strata schemes. Under the current law, the main income for stratified properties comes from the maintenance fund and the sinking fund.

\section{Maintenance Fund}

Maintenance charges refer to all charges imposed and other moneys derived from the sale, disposal, lease or hire of mortgages, and debentures vested in or acquired by the Management Corporation (MC). It also includes the moneys lawfully received by the MC including interest, donations and trust. ${ }^{23}$ These charges go into the Maintenance Fund.

\section{Sinking Fund}

All buildings mature and sooner or later become dilapidated properties. The cost of maintenance for the building increases as the buildings age. In dealing with maintenance, there are circumstances which are unexpected and sometimes go beyond the projection of the management. At times, buildings need to be refurbished to maintain the substantial value of the properties. In this situation, the collection from maintenance charges may turn out to be insufficient. The demand seems to be more beneficial for small strata schemes which are sometimes owned by and among family members. The family may decide to either establish a foundation or create an endowment that will ensure long term sources of income for the maintenance of their buildings without worrying about the

23 Section 50 of the SMA 2013. 
challenges in the monthly collection of the maintenance charges. In addition, and realising the need to have a separate account for this unexpected maintenance cost, most strata laws in many jurisdictions provide for collection of a sinking fund. ${ }^{24}$

SMA 2013 defines "sinking fund account" as an account required to be opened and maintained by a developer, Joint Management Body (JMB) or the MC (Section 2 SMA). The Joint Management Body (JMB) or Management Corporation (MC) or subsidiary MC under sections 11, 24, 51, 61, of the SMA 2013 as the case may be, are legally entrusted to manage the sinking fund account and make decisions for matters relating thereto. These sections, read with sections 10, 23, 50, 60 of the SMA 2013 , illustrate that the sinking fund is different from the "maintenance fund". Section 46 and Schedule H of the Housing Developers (Control and Licensing) Regulations 1989 (amended in 2002) stipulate that the sinking fund (called "special fund" in the STA 1985) can be used to meet major liabilities of the stratified properties. In addition, Regulation 20 (1) of Schedule H of the Housing Development (Control and Licensing) Regulations also allows the vendor, upon the date the purchaser takes vacant possession of the said parcel, to open and maintain a separate sinking fund for the purposes of meeting the actual or expected liabilities in respect of the following matters - such as the painting and repainting of any part of the common property; the acquisition of any movable property for use in relation with the common property; or the renewal or replacement of any fixture or fitting comprised in the common property. The amendment to the Housing Developers Regulation that was made in 2001 requires the developer to open an account to be called a 'sinking fund' without the need to form the MC which would delay the process of collection of this special fund for specific maintenance purposes.

Under the Housing Development (Control and Licensing) Act, Clause 20(2), the purchaser shall, on the date he takes vacant possession of his parcel, contribute to the sinking fund an amount equivalent to ten (10) per centum (10\%) of the service charges. The contribution shall be payable monthly in advance. This provision has been adopted in the new SMA 2013 thus streamlining it in a more clear and standardised way.

24 Sections 70, 73(2), 80(2) of the Strata Scheme Management Act for NSW, Australia, Section 39 of the Building Maintenance and Strata Management Act, (CAP 30C). 
In Australia, the sinking fund is put under the control of the Owners Corporation. ${ }^{25}$ It generally refers to a large capital expenditure fund which is used to pay for the long term expected and unexpected costs of repairs and replacement. It may include carpet replacement, painting of common property, changing of roof and such. It is always advisable to create an account for unexpected emergencies or contingencies that may happen in the future. ${ }^{26}$ In Malaysia, some developers collect this fund by way of governing documents, such as a Deed of Mutual Covenants prior to the establishment of a MC while others rely on the provisions of the Schedule H of the Housing Developers Act. Using whichever method, the collection of sinking fund should not be confused with maintenance charges, which are meant for the general maintenance and management of the common property and also for the other services, which the developer has put commitment to.

The fund may also be used to cover expenses for painting the common property, purchasing assets such as mowers or washing machines, renewing or replacing any fixtures on the common property and any other property owned by the MC. In Australia, the same fund is used to cover replacing, repairing or making good the common property, to cover debts which are not covered by the administrative fund (similar to the maintenance fund in Malaysia) as well as other capital expenses. ${ }^{27}$

Apart from the allocation for the sinking fund, long term planning for strata maintenance and management also requires an allocation for depreciation in value of the properties as these properties are aging. The need for a depreciation report ${ }^{28}$ lies behind public policy cause. The requirement arises out of the view that long term and appropriate planning is necessary for each strata scheme in order to plan for future

\footnotetext{
25 Similar body to the Management Corporation in Malaysia.

26 www.strataman.com.au.accessed $4^{\text {th }}$ August 2016.

27 S 75(2) Strata Schemes Management Act 1966.
}

28 Depreciation report includes an on-site inspection and inventory of the common property and building systems; a schedule of anticipated maintenance, repairs and replacement costs for common expenses projected over 30 years; and a financial forecast which includes costs and cash-flow funding models for the contingency reserve fund. As the report is essentially not common to all strata jurisdictions, the sample report proposal is available online in Canada by the Home Owner's Association to assist strata corporation or management corporation. 
maintenance of buildings. With this, each management corporation would be able to protect their common property and other common assets of their strata scheme. This is in line with the view that proper maintenance and design will reduce the costs related to common property and asset. ${ }^{29}$ Preparation for long term building maintenance plan will help to prolong the age of buildings. A depreciation report provides estimation for the service life of an asset over the next few years. It works through a report on all repair, renewal and maintenance costs anticipated for each asset for a 30 years planning. Malaysia is still lagging behind other jurisdictions in several aspects of its law and management, among others, the depreciation report. It is obvious that there is no provision on the requirement to prepare a depreciation report under the Acts.

The SMA 2013 continues to provide for the maintenance account, ${ }^{30}$ sinking fund, ${ }^{31}$ deposits to rectify defect, insurances as well as the establishment of a Tribunal to resolve problems relating to strata management. Nevertheless, the need for the depreciation report to help owners or future owners to determine the value of their stratified properties is yet to be seen as important but perhaps is already due in Malaysia. The justification for a depreciation report in preparation for long term maintenance and management of strata scheme is in line with the nature of waqf properties which have to be permanent in nature. The use of the report is justifiable to support the need for use of money in a waqf fund for long term benefit of the strata schemes.

Apart from collection of money or contributions to the sinking fund which sometimes is a burden to the developer or Joint Management Body or even the $\mathrm{MC}$, the law has a general provision allowing the management bodies to collect money. For example, section 50 (2)(e) of the SMA allows the collection of money from interest, donation or trust. The preceding discussion on the need to continuously raise funds for the maintenance for the day to day running and management of stratified properties as well as the requirement to allocate a special fund known as the sinking fund to cater for special needs of long-term maintenance supports the relevancy of cash waqf for the management and maintenance

29 Edward L. Wilson, "Strata Property Acts -Depreciation Reports" (2012) in www.Lawsondell.com accessed on 5th August 2015.

30 S. 50;s. 52;s. 60; s. 62; s. 65; s. 66 of the Act 2013.

31 S. 51 ; s. 52; s. 61 ; s. 68 of the Act 2013. 
of stratified properties. Waqf commemorates the dedication of properties, moveable and immoveable, tangible or intangible for certain general or specific purposes. This dedication is forever, inalienable and cannot be transferred or sold by anybody who is entrusted to manage the properties or known as mutawalli or nazir. Section 50 (2)(e) prepares a legal basis for the Mutawalli or trustee to collect money under the concept of cash waqf subject to other requirements imposed by the law such as the need for approval from the Mutawalli to do as such. Although the present law on stratified properties does not provide for waqf specifically, it is suggested that albeit the proper amendment of the law, the current provisions on the management of funds may be employed to facilitate waqf. In this respect, waqf may fall under 'charitable trust or donation'.

\section{MANAGEMENT OF STRATA FINANCES}

Managing strata finances are among the key responsibilities of any strata executive committee and specifically, the treasurer. The major functions of the treasurer are to take charge of the day-to-day accounts, financial recording, levy gathering and other related matters including the recoupment of taxes or fee arrears. However, a good and active treasurer can add enormous value to the scheme, both financially and in terms of quality of work. The accounts received by the treasurer should be recorded and reported on a monthly, quarterly or annual basis. In addition, an administrative fund is generally employed to meet recurrent expenses, for instance, any contract payments to strata and building managers, insurance premiums, water and electricity charges as well as ongoing maintenance contracts such as those for lift, pool and gardening. These funds may be added and deleted from time to time with approval from the members through the AGM. Under each of these funds there should be details of the revenue collected.

In Australia, more than $85 \%$ of the revenue collected through the sinking funds are under-capitalised. ${ }^{32}$ It means that an owners' corporation $^{33}$ (similar to MC) has a duty to prepare for every 5 years, a forward plan with costing for maintaining its buildings. This is called a

32 http://www.sinkingfundplan.com.au/sinkingfund.html accessed on 21 June 2015.

33 This body is called Management Corporation under the Malaysian law. 
Sinking Fund Forecast and the strata corporation has to list the cost to be spent on each item of maintenance in the next 10 years. It is a long-term maintenance budget. It is observed that adoption of waqf principles to Sinking Fund management and investment is of advantage as it offers a permanent and sustainable source of income. In addition, the current law on management of strata schemes is meticulous and transparency is paramount. The present financial formula in the strata scheme may be used in line with the Malaysian Financial Reporting Standards introduced by the Malaysian Accounting Standards Board ('MASB') for waqf by waqf management but with consideration of the Islamic requirement of Shariah compliance in all activities involving the utilisation of the waqf fund. ${ }^{34}$

\section{PROMOTING SUSTAINABLE WAQF}

The discussion above has emphasised the importance of finances and financial management in stratified properties management. Waqf properties and waqf products may be employed within the financial and investment of strata schemes to become a source of sustainable income for strata management. Maintenance of common properties may be sustained using the benefits from waqf properties or cash endowed in perpetuity. ${ }^{35}$ A lump sum as capital from cash waqf or sukuk may be invested or converted into the form of waqf assets for the development of strata properties. The usufruct (manfa' $a h$ ) of the waqf assets may be used to support other commitments and maintenance of facilities in the schemes provided that the activities or the facilities are consonant with Shari'ah.

Among the important principles of waqf is that the activities must give 100 percent preference to the intention of the donors and the benefits must be in perpetuity. ${ }^{36}$ The activities also must not be in

34 MASB issued a research paper on waqf accounting in 2014. See: http://www.masb.org.my/pdf.php?pdf=MASB\%20Research\%20PaperWaqf.pdf\&file_path=pdf, accessed on $8^{\text {th }}$ Dec. 2017.

35 There are differences of opinion among the jurists as to the perpetuity of the subject matter of waqf. See, Abdul Hamid Mar and Mohammad Tahir Sabit, Waqf Property Concept, Management, Development and Financing, (UTM: Skudai, Johore, 2014) 39.

36 Ibid. 
contradiction to Shariah. Islam does not prohibit a pledge by a non Muslim and neither does it restrict any kind of enjoyment by the non Muslims. ${ }^{37}$ The donor is also allowed to pledge something which will also benefit himself. ${ }^{38}$ These principles are most important to facilitate the implementation of waqf in strata schemes in Malaysia.

Waqf can either be based on a one-off donation or a pledge over an agreed period of years. In the context of maintenance and management of stratified common properties, the mutawalli, i.e. the State Islamic Religious Council ('SIRC') ${ }^{39}$ must delegate the power to either the MC or the JMB, as the case may be, or any other person appointed or authorised by the MC and JMB to act on their behalf to manage the building. The SIRC may also delegate the power to monitor strata managers to the Commissioner of Buildings, adopting the current requirement under the SMA.

\section{RESPONSIBILITIES OF THE INVESTMENT MANAGER}

Any MC or the JMB may delegate duties relating to waqf management to any authorised agent who is well versed in investment who can be referred to as a strata manager. A Muslim scholar suggests that investment of waqf assets must be organised by an agent. ${ }^{40}$ It is suggested that the specific responsibilities of the investment office or consultant are to be determined clearly and endorsed by the $\mathrm{MC}$ or the members of the strata scheme in an AGM. The document includes, among others, matters pertaining to investment policy including benefit sharing portion, return objectives, relevant risks, asset allocation guidelines, provisions for rebalancing, appropriate portfolio and asset-class benchmarks, and considered views on indexing and currency hedging. A strong

37 Al Shirbini al Khatib, Mughni al Muhtaj, The Book of Waqf (translation) Nicholas Mahdi Lock, (IBFIM: Kuala Lumpur, 2015) 36-37.

38 This view is approved by Hanafi and Hanbali Schools of law. See, Al Shirbini al Khatib, Mughni al Muhtaj, The Book of Waqf (translation) Nicholas Mahdi Lock, ( IBFIN Kuala Lumpur, 2015).14-15, 38.

39 Under the state laws relating to waqf in Malaysia, the State Islamic Religious Council is the sole-trustee of all waqf assets in the state.

40 'Abd al Malik al-Ja'li, Idarah wa Tathmir Mumtalakat al-Awqaf, (al-Bank al-Islami li al Tanmiyyah, Jeddah, 1989), 434. 
investment policy provides a good foundation for effective endowment management. Other elements such as managing risks and how risks should be addressed are the keys to avoiding disasters and producing strong results. A good investment agent may also consider researching new asset classes and strategies as well as performing due diligence on new and existing money managers. To a certain extent, hiring and firing managers is necessary where and when appropriate.

Many waqf scholars have written about and support cash waqf including Cizakca and Tunku Alina, both of whom propose the establishment of a waqf model where the concept of cash waqf can be used in contemporary times to serve the social objectives in the society. ${ }^{41}$ Similarly, Elgari proposes the establishment of Qard Hassan ${ }^{42}$ bank as a waqf non-profit intermediary which offers interest free loans. ${ }^{43}$ The capital of the bank would come from monetary (cash) waqf donated by Muslims. Kahf ${ }^{44}$ and Ahmed ${ }^{45}$ proposed microfinance institutions based on zakah, waqf, and sadaqah. They suggest that the returns from awqaf and funds from sadaqat can be used to finance productive social enterprises at subsidised rates. Zarqa points out there exist various institutions and structures that Islam has instilled to redistribute income

41 Cizacka,M. "Ottoman Cash Waqfs revisited: The case of Bursa 15551823". (Manchester: Foundation for Science Technology and Civilisation, 2014). See also, Chowdhary M.S.R., Problems of Waqf Administration and A Proposal for Improvement: A Study of Malaysia,Journal of Internet Banking and Commerce, Vol. 17(April 2012),2-8. Tunku Alina Alias, "Venture Capital Strategies in Waqf Fund Investment and Spending", ISRA International Journal of Islamic Finance, Vol.4, Issue 1 (2012) 99. Where a bank deposit is considered a loan for bank to use.

43 El-Gari, M.A. "The Qard Hassan Bank," paper presented at the International Seminar on Nonbank Financial Institutions: Islamic Alternatives, March 1-3, 2004 in Kuala Lumpur, jointly organised by Islamic Research and Training Institute, Islamic Development Bank and Islamic Banking and Finance Institute Malaysia.

44 Kahf, 2004

45 Ahmed, H. (2007). Waqf based Microfinance: Realizing the Social Role of Islamic Finance: Paper presented at the International Seminar on Integrating Awqaf in the Islamic Financial Sector, March 6-7. Singapore. 
and wealth to fulfill the basic needs of the members of the society ${ }^{46}$ such as zakah, waqf and qard hasan. On the other hand, the Malaysian Islamic capital market, through the Security Exchange Commission (SEC) has developed a model of musharakah sukuk to generate funds for the development of awqaf properties. All the Islamic financial products are to the advantage of the strata schemes management instead of resorting to loans although it is permitted under the strata laws.

\section{FUND COLLECTION FOR A STRATA WAQF PROJECT}

Waqf can be divided into waqf am (general waqf) and waqf khas (waqf for specific purpose or private waqf). In relation to waqf for stratified properties, it is proposed in this article that two models are possible, namely:

i. Using Cash Waqf as a crowd funding facility to generate funds for the maintenance of common properties or identified common properties in a strata scheme using the existing fund generating mode;

ii. The use of sukuk by dedication of certain units of parcels in a strata scheme, the benefits which may be utilised to maintain the common property of the scheme. A similar mode of sukuk can also be used to initiate development of waqf land in which discussions have been deliberated by many authors.

\section{Cash Waqf Fund}

The cash waqf $f^{77}$ is a philanthropic foundation established with money to support services to mankind in the name of God. A cash waqf fund may be operationalised to solicit cash waqf.

46 Zarqa, M.A.," Islamic Distributive Schemes", in Iqbal, M. (Ed.), Distributive Justice and Need Fulfillment in an Islamic Economy, ( The Islamic Foundation, Leicester. 1988) 163-216.

47 Cash waqf was supported by the Ottoman Sultans, because funds were financed in the expansion of Islam in Europe, see, Ç. Murat, "Awqaf in history and its implications for modern Islamic economies," Islamic 
There are many ways of collecting cash waqf. The donors (waqifs) of this fund will give their cash money for the purpose of financing the development of awqaf land/building/properties or specifically, in the context of a strata scheme, cash waqf may be converted to an asset in which the benefits may be dedicated to facilitate the maintenance of common properties. The waqf trustee will manage these benefits and the fund will be utilised for maintenance of common properties or in a bigger scale, the cash waqf may become capital for revolving loans for development of awqaf properties. Since this fund will be generated out of cash waqf contributions solicited from individuals such as the strata owners and institutions including the government, therefore, its administrative expenditures will be covered from the service charges which are permissible in Shariah as long as they represent the actual cost of administering a loan. In this article, the proposed donors are the owners of the strata scheme. The role of cash waqf in property development requires consideration on the loss and profit and most effective way to cover the cost. Thus, a proper mechanism which can guarantee the return of the capital either based on Build, Operate and Transfer (BOT) or lease instrument must be closely calculated by the strata managers.

On the other hand, a cash waqf fund may also be utilised on Mudharabah $^{48}$ or Musharakah ${ }^{49}$ mode of finance basis and its profits

Economic Studies, vol. 6, no. 1, Jeddah: IRTI \& IDB (1998). In Malaysia, the Fatwa Committee of the National Council for the Religion of Islam has confirmed the legality of Cash Waqf at its 77th meeting on 10th to 12th. April, 2007.

In the Mudharabah transaction, a mudharib provides the management expertise which is treated as a form of capital while the investor ( $r a b b a l$ mal) will provide the capital. The return profits will be shared between the $m u d h a r i b(\mathrm{~s})$ and the investor(s) based on ratio mutually agreed to by the parties involved. The investor bears all losses of invested assets (cash or other forms of capital). The entrepreneur must not bear any of the losses attributable to invested capital. The entrepreneur is not allowed to take any form of remuneration other than profit-share. Technically, the entrepreneur has no recompense for his efforts unless the project is profitable or unless there is a guaranteed wage.

The Musharakah is a sharing model where parties involved in a partnership contribute capital and have the right to exercise executive powers in the running of the project based on agreed terms. These contributions can be 
will then be utilised for a philanthropic objective such as helping the poor while preserving the principal of the mudharabah and musharakah characteristics. A cash waqf fund may also receive special cash waqf contributions which can be utilised for the development of specific waqf assets or properties. In this case, the cash may be transformed into either a material addition to the waqf such as buildings, equipments, furnitures, or other types of services including the security costs, cleaning services or utilities, etc. Alternatively, this cash may be transformed to a special cash waqf fund to develop certain identified waqf projects such as to finance the parking lots, swimming pool, prayer room (musolla) or other educational institutions such as day care for children or the elderly.

As stated above, in the first option, cash waqf may be converted to other assets and in the second option, cash waqf (waqf of cash) is clearly defined to be used for a certain specific facility such as providing fire extinguishers in the common properties. In this type of cash waqf, the costs and waqf property (mawquf) must be clearly identified. Similarly, the donor (waqif) must be clear on what type of facilities would form the mawquf alaih. Hence the waqf declaration (sighah) must also be made clear. All these facilities will add value to the services offered in a strata scheme.

It could be seen that apart from utilising cash waqf for maintenance of common property, cash waqf may be utilised especially, in the early years of strata schemes to complete any additional development of the schemes. Moreover, waqf funds would be in high demand for aged buildings - to be used to refurbish and maintain the necessary repairs and renovation. During the Ottoman period in Turkey, it is learnt that there were various types of waqf by its people such as waqf for the repair of clocks in the mosque, waqf for Rest and Restroom Area known as caravanserai and many others. ${ }^{50}$ The culture of waqf has helped the government to provide and maintain public utilities.

It is believed that through innovative cash waqf management systems, various parties can reap the benefits of waqf including the strata owners. What is needed most is to formulate a cash waqf institutional setup and establish their networking relationship throughout the country

subject to profit sharing in a ratio mutually agreeable to all the investing parties.

50 Douglas A Howard, The History of Turkey, $2^{\text {nd }}$ Edition,( Santa Barbara California:Greenwood,2016) 50. 
with a view to increase their performance towards an efficient and need based management of waqf affairs and systems. Consequently, total policy dimensions at micro and macro perspective can also be framed to meet the diversified objectives of innovations and development in the cash waqf management systems complying with the Shariah guidelines.

\section{Musharakah Sukūk}

Many waqf institutions simply do not have the funds to develop new capacity while continuing their existing work. Strata managers must always be creative to find ways to increase assets and funds. One of the ways is through the issuance of Sukuk (Islamic bond) to purchase a few units of stratified properties and then to dedicate the unit as waqf, the benefit of which shall be used to maintain common properties. The main objective of introducing sukuk for waqf is to provide long term support with a focus on building capabilities and long term investment especially for commercial stratified properties.

Sukuk is an Islamic financial certificate based on Shari 'ah. The issuer of a sukuk sells this certificate to an investor or a group who then rents it back to the issuer for a pre-determined rental fee. The issuer then makes a promise to repurchase the sukuk at a future date for certain values either based on the net asset value, market value, cash equivalent value or any price agreed upon at the time of purchase. The Sukuk manager can only guarantee to repay the capital to Sukuk holders at face value in cases of negligence or violation. Sukuk holders in a mudharabah or musharakahbased structure need to understand that the Sukuk holder must have some risk in these structures. Shariah principles encourage the sharing of risk and profit. $^{51}$

Most importantly, the sukuk product links the returns and cash flows of the financing to the assets purchased, or the returns generated from an asset purchased. This is because trading in debt is prohibited under the Shariah. Therefore, the primary condition of the issuance of sukuk is the existence of assets on the balance sheet of the corporate body, banking or other financial institutions or any other entity that wants to mobilise

51 The Accounting and Auditing Organisation for Islamic Financial Institutions (AAOIFI) Statement,2008. 
financial resources through sukuk. The main concepts of sukuk are concerned about (i) transparency and clarity of rights and obligations; (ii) that income from securities supports the purpose for which the funding is used, and not simply comprising interest; (iii) those securities should be backed by real assets, rather than paper derivatives.

There are several types of sukuks. Ijra sukuk and musharakah sukuk are popular in the real estate financing and to create funds for construction of new complexes. The development of waqf assets i.e the purchase of strata units or lots through the issuance of sukuk may be most suitable by using the musharakah financing principle. Musharakah sukuk is an important vehicle for it represents new source of funds on basis of profit and loss-sharing. The demand may not be trivial in residential stratified properties but worth venturing for commercial strata titled properties.

Having explained the above, it is again acknowledged that the strata managers may not be able to work on their own but need to engage a consultant investor to properly manage their income. It is recognised that besides the property asset, a good and consistent flow of cash income is vital for strata development as most of the maintenance charges involved cash expenditure. A lesson learnt from Warees Property Investment Pvt. Ltd. Singapore ${ }^{52}$ is that although none of the staff have Shariah background, the company works in close contact with the Singapore Mufti's office. All unclear terms are referred to the Mufti's office. It is proposed that the JMB or the MC may establish a Shariah Advisory Board in the strata scheme. Alternatively, it is advisable to refer matters relating to Islam and Shariah compliance issues to the State Islamic Religious Council or the Fatwa Committee for confirmation.

A specific sukuk project is established to finance common property or specific cash waqf proceeds are used to redeem sukuk where the proceeds from sukuk are later used, for example, to finance common properties or to purchase a specific lot of strata titled properties. In this respect, the waqf assets may be used as a sustainable source of fund to maintain any part of common properties In the above model, the Developer/JMB/MC establishes a specific cash waqf collection project by themselves or by engaging a waqf agency involving the residents of the strata scheme or the public with the permission from the Mutawalli. The

52 It is a real-estate company in charge on endowment assets management under the State Islamic Religious Council of Singapore. 
nazir or manager appointed by the Mutawalli is responsible to manage the pooled fund until it is sufficient to finance maintenance services of the common property of the strata scheme either for day to day maintenance or for contribution to the sinking fund of the scheme.

\section{THE WAQF MANAGER}

Waqf involves a pledge of capital or moveable or immoveable assets in perpetuity. The waqf assets shall provide a consistent flow of income to support the strata scheme planning and future investment reflecting the intention (niyyat) of the endower. As it grows, it is acknowledged that there is a need for full-time and professional management of endowments. Through waqf, there will be opportunities for the waqf manager ${ }^{53}$ or investment professionals to venture into one type of Islamic product that will benefit the whole ummah. In strata properties, there are qualified property agents or Real Estate Investment Trust (REIT) company or may be among the line-up of the MC who are expert in property management and investment. Thus, waqf will provide a new method of investment within Shariah.

Success stories of waqf based charitable institutions are enormous. There are many colleges and universities with large endowments and capital hire one or more investment professionals or investment staff. Their task is to profitably manage and invest the endowment in order to meet the organisation's financial and investment objectives. Oxford and Cambridge Universities are among the top universities in the world which have big assets belonging to foundation which are very much similar to waqf.

An investment company or agency is either a single individual or dozens of professionals, depending on both the size and complexity of the endowment and the priority of an institution. An investment office is typically led by a chief investment officer (CIO) and supported by senior investment officers. The latter usually specialize in one or more asset

53 "Manager' refers to someone who controls or administers a business or the affairs of an organisation or a group of people, see, Oxford Dictionary at http://www.oxforddictionaries.com/definition/english/manager accessed on 5th August 2015. 
classes, and may be supported by investment analysts, the junior members of the team. ${ }^{54}$

The expected educational background for those pursuing a career in endowment management includes majors or substantial course work in economics, finance, accounting, investments and/or business. It is generally viewed that having a Masters Degree in Business Administration would be an added point for those who wish to advance beyond the analyst level. Analysts may be hired from the accounting or finance areas of the institutions. ${ }^{55}$

The ability to perform strong due diligence on assets management and strategies is key to strong investment performance. An ability to accurately evaluate people including their strengths, weaknesses, character, competencies and philosophy will greatly assist in this process. Continual education process through attending industry conferences is of great help in establishing relationships with fellow investment professionals and in educating oneself on all aspects of the institutional investing business. ${ }^{56}$ Again, it is emphasised that waqf management, especially in dealing with real estate properties, requires qualifications beyond shariah qualification and legal background.

In Malaysia, the need for waqf investment agents who are well versed in both, conventional and Shariah products is overdue but challenging. Many SIRCs are still having problems of lack of expertise in handling waqf due to the diverse nature and fast development of waqf initiatives. ${ }^{57}$ As for stratified properties management, the ability to combine both, the management of funds from the existing sources of income as determined by the law and cash waqf or sukuk would be a potential way in managing strata properties employing waqf funds. Nevertheless, the need for a sustainable source of funds is real. If, a strata scheme lacks qualified

\footnotetext{
54 "A career in Endowment Management", at http://www.investopedia.com/article/financialcareers/09/endowmentmanagement-career.asp\#ixzz3fDzTZrN8 accessed $4^{\text {th }}$ August 2015.

55 Ibid.

56 Ibid.

57 Siraj S.A and Kharbhari, "Y. Financial Accountability of Waqf (Pious Endowment) Institutions in Malaysia: The Case of Budgeting Practices in State Islamic Religious Councils", Conference Paper, at http://www.researchgate.net/publication/261838385

.doi:10.13140/2.1.1138.5289. accesed on 3 August, 2015.
} 
personnel to run the management, but with strong financial background, the Commissioner of Buildings may appoint a managing agent to manage the properties as provided by the law. 58

\section{CONCLUSION}

It is believed that waqf has great potential for strata schemes and vice versa. A Mutawalli or waqf manager should regard a strata scheme as a platform to implement waqf either as a subject matter of waqf, potential waqif and beneficiaries where it complements the current system of management of stratified properties. A strata manager or Mutawalli should look at waqf as an opportunity to seek alternative funding and creating a secured asset for sustainable strata scheme. The findings show that apart from the need for specific skills in managing strata schemes, stratified properties management also requires good flow of income and secured assets which are essential features in waqf. Waqf may provide alternative modes of financial assistances and investments for the maintenance and management of common properties in strata schemes. Formulating a Waqf Code of Governance would be able to enhance the professionalism of waqf managers. The sense of belonging and common responsibilities are the additional factors that can boost waqf activities in strata schemes. The prospective challenge is to create awareness concerning waqf benefits among the owners as well as the public and the need to find qualified managers to handle waqf investment activities so that the returns can meet the expectations of the endowers and are Shariah compliant. Conversely, waqf implementation would create more job opportunities for strata managers and investment consultants.

Contributions for strata maintenance come in two forms, namely, the management fund and the sinking fund. Studies have shown that maintaining sustainability of these sources of income becomes the hardest task of the Management Corporation (MC), the Joint Management Body (JMB) or the developers. ${ }^{59}$ As a result of not having

58 Section 86 and Section 87 of the SMA 2013.

59 Hasliza Ahmad, "Kajian Ke Atas Operasi Pengurusan Kediaman Berstrata Kajian Kes: Pangsapuri Johor Bharu”, (Undergraduate Dissertation, UTM: Skudai, 2008). 85; Fakhrudin, Isma Haniza, Suleiman, Mohd Zailan and Talib, Roslan (2011) “The Need to Implement Malaysia's Building and 
enough funds, the developers or property managers have claimed that they could not provide good management or services to strata owners and occupiers. ${ }^{60}$ At the same time, it is generally upheld that strata properties maintenance is needed throughout the entire period that the building is being used or is in occupation. ${ }^{61}$ Realising the need for sustainable maintenance and management of stratified properties, this article proposes waqf as an alternative solution to ensure sustainable sources of income for maintenance of common properties in strata schemes. Having proposed this, it is generally recognised that it may be too much to expect a managing agent or a strata manager to be able to supervise the running of a religious endowment in a strata scheme. Nevertheless, over time and with proper training, it could be made viable.

It is also acknowledged that strata managers are occupied with other administrative and social duties thus financial responsibilities may become an unaccomplished task. ${ }^{62}$ As such, waqf consultants or waqf project managers with experience in corporate planning, investment and accounting are in demand. Otherwise, it is still feasible but with a long term and more expensive waqf management including training for strata managers or JMB or the MC committees on the concept, roles of waqf and how waqf instruments can be utilised to generate sustainable income for the organisation. It could be seen that in various strata jurisdictions, the management of stratified properties have been spearheaded by preparing various laws, regulations, House Rules and even recognising encumbrances, as part of a management scheme with comprehensive administrative and ethical guidelines. ${ }^{63}$ While waqf has a lot to offer as a

Common Property Act 2007 (Act 663) in Building Maintenance Management", Journal of Facilities Management 9(3)(2011) 170.

60 Tiun Ling Ta, "Managing Highrise Residential Building in Malaysia: Where Are We",(Paper presented at the $2^{\text {nd }}$ NAPREC Conference, INSPEN, Bangi, 2009) p. 1.

61 Lee, How Son and George C.S. Yuen, "Building Maintenance Technology, (The MacMillan Press Ltd (1993) cited in Fakhrudin, Isma Haniza et.al (2011) 174. See Above note 9.

62 Teo Poh Siang, A Practical Guide to Strata Management in Singapore, (Singapore Book Publisher: Singapore, 2012) 85-88.

63 The trend is common either in Australia, Singapore, New Zealand, Canada or United States. The management of strata properties are minuted in detail to avoid vagueness and discrepancies of the laws. 
long term sustainable financial resource, the future lies in the preparation of managers, well trained in property investment and management. 